\title{
Göğüs hastalıkları yoğun bakım ünitesinde mikroorganizmaların dağılımı ve antibiyotik direnç profili: Tek merkezli çalışma
}

\author{
Hasan HASANZADE ${ }^{1}$ (ID) \\ Aslıhan GÜRÜN \\ $\operatorname{KAYA}^{\mathbf{1}}$ (ID) \\ Aydın ÇiLEDAĞ ${ }^{\mathbf{1}}$ (ID) \\ Serhat $\operatorname{EROL}^{\mathbf{1}}(\mathrm{ID})$ \\ Fatma ÇiFTÇi ${ }^{1}($ ID) \\ Haluk GÜRiZ²(ID) \\ Akın KAYA $^{\mathbf{1}}($ ID)
}

\author{
1 Ankara Üniversitesi Tıp Fakültesi, Göğüs Hastalıkları Anabilim Dalı, \\ Ankara, Türkiye \\ ${ }^{1}$ Department of Chest Diseases, Ankara University Faculty of Medicine, \\ Ankara, Turkey \\ ${ }^{2}$ Ankara Üniversitesi Tıp Fakültesi, Tıbbi Mikrobiyoloji Anabilim Dalı, \\ Ankara, Türkiye \\ ${ }^{2}$ Department of Medical Microbiology, Ankara University Faculty of \\ Medicine, Ankara, Turkey
}

Makale atıfı: Hasanzade H, Gürün Kaya A, Çiledağ $A$, Erol S, Çiftçi $F$, Güriz $H$ ve ark. Göğüs hastalıkları yoğun bakım ünitesinde mikroorganizmaların dağııımı ve antibiyotik direnç profili: Tek merkezli çalışma. Tuberk Toraks 2021;69(1):9-20.

Yazışma Adresi (Address for Correspondence)

Dr. Aslıhan GÜRÜN KAYA

Ankara Üniversitesi Tıp Fakültesi,

Gögüs Hastalıkları Anabilim Dalı,

ANKARA - TÜRKIYE

e-mail: aslihangurun@hotmail.com

OTelif Hakkı 2021 Tüberküloz ve Toraks. Makale metnine www.tuberktoraks.org web adresinden ulaşılabilir.
ÖZ

Göğüs hastalıkları yoğun bakım ünitesinde mikroorganizmaların dağılımı ve antibiyotik direnç profili: Tek merkezli çalışma

Giriş: Yoğun bakımda takip ve tedavi edilen hasta grubunda, hastaların genel durum bozukluğu ve bu hastalara invaziv işlemlerin sık uygulanmasından dolayı enfeksiyonların gelişme riski, diğer servislerde yatan hastalara göre daha yüksek, hastaların hastanede kalış süreleri daha uzundur. Ayrıca bu hasta grubu, geniş spektrumlu antibiyotiklerin ampirik olarak yaygın ve kontrolsüz kullanımı nedeniyle dirençli enfeksiyonlara da yatkın hastalardır. Bu nedenle yoğun bakım hastalarında uygun ampirik antibiyotik tedavisini belirleyecek verilere gereksinim vardır. Bu çalışmada yoğun bakımda yatan hastalardan alınan örneklerden üreyen mikroorganizma dă̆ılımının ve antibiyotik direnç profilinin belirlenmesi amaçlanmıştır.

Materyal ve Metod: Çalışmamıza Ankara Üniversitesi Tıp Fakültesi Göğüs Hastalıkları Yoğun Bakım Ünitesinde Aralık 2016-Aralık 2017 tarihleri arasında 24 saatten uzun süre yatan hastalar dahil edildi. Hastaların demografik özellikleri, ek hastalıkları, klinik bulguları, balgam, trakeal aspirat kan, idrar, gaita ve varsa yara kültür örneklerinin mikrobiyolojik sonuçları ve antibiyotik duyarlılık test sonuçları prospektif olarak kaydedildi.

Bulgular: Çalışmaya 150'si erkek 137 kadın olmak üzere toplam 287 hasta dahil edildi. Tüm hastaların yaş ortalaması 69,96 \pm 14,4 yıl idi. Çalışma süreci boyunca 287 hastadan 1053 kültür örneği alındı ve bu kültürlerden 223'ünde 
üreme saptandı. Üremelerin \%55,1'ini gram negatif bakteriler oluşturmaktaydı. En sık saptanan mikroorganizmalar \% 16,6 oranı ile Acinetobacter spp, \% 14,8 oranı ile Staphylococcus, \% 10,8 oranı ile Klebsiella olarak tespit edildi. En sık saptanan mikroorganizma olan Acinetobacter suşlarında kolistin direnci \%8,3 iken, çalışılan diğer antibiyotik gruplarına \%97-100 oranlarında direnç tespit edildi. Ikinci sıklıkta saptanan mikroorganizma olan 33 Staphylococcus üremesinin 17'si S. aureus, 16'sı koagülaz negatif Staphylococcus olarak bulundu. S. aureus üremelerinin \%29,4'ü metisilin dirençli iken, vankomisin direnci saptanmadı. Koagülaz negatif Staphylococcus suşlarında ise metisilin direnç oranı \%62,5 iken, vankomisin direnci yoktu. Klebsiella üçüncü sıklıkta saptanan mikroorganizma olup, beta laktamaz üreten Klebsilla suşu oranı \% 62,5 olarak saptandı. Gentamisin \%20,8 direnç oranıyla Klebsiella üremelerinde duyarlılığı en yüksek antibiyotik olarak bulundu. Üremelerin \% 9,4'ünü oluşturan Pseudomonas aeruginosa'nın kolistine direnci saptanmazken, piperasilin/tazobaktama \%42,8, tobramisin, imipenem ve meropeneme karşı \%50, seftazidime ise \%61,9 oranlarında direnç saptanmıştır. Acinetobacter üremesi olan hastalarda hastanede yatış süresi (23 gün [10-34] vs 12.5 gün [5-24], $p=0,011)$ ve mortalite oranı (\%62,5 vs \%37,5, p=0,008), üreme olmayan hastalara göre anlamlı olarak daha yüksek bulundu.

Sonuç: Sonuç olarak yoğun bakımda yatan hastalardaki üremelerin büyük bir kısmını gram negatif basiller oluşturmaktadır. En sık üreyen mikroorganizma olan Acinetobacter suşlarında direnç oranı yüksek olup, Acinetobacter enfeksiyonu varlığı uzamış hastane yatışı ve mortalite ile ilişkili bulunmuştur

Anahtar kelimeler: Antibiyotik; antibiyotik direnci; enfeksiyon; yoğun bakım

\section{ABSTRACT}

The distribution of microorganisms and antibiotic resistance profile in pulmonary critical care unit patients: A single-centre study

Introduction: The patients in the intensive care unit have a higher risk of infections because of the poor general condition of these patients and the frequent application of invasive procedures with longer hospitalization length. Also, this group of patients tend to have resistant infections due to empirically widespread and uncontrolled use of broad-spectrum antibiotics. Hence, data are needed to determine appropriate empirical antibiotic therapy in intensive care patients. In this study, it was aimed to assess the distribution of microorganisms and antibiotic resistance profile from the samples taken from the patients in the intensive care unit.

Materials and Methods: Patients who were hospitalized in Ankara University Faculty of Medicine Chest Diseases Intensive Care Unit for more than 24 hours between December 2016 and December 2017 were included in our study. Demographic characteristics, comorbid diseases, clinical findings, results of sputum, tracheal aspirate, blood, urine, gaita and pus culture samples and antibiotic susceptibility test results were recorded prospectively.

Results: A total of 287 patients, 150 males and 137 females, were included in the study. The mean age of all patients was $69.96 \pm$ 14.4 years. Two hundred twenty-three positive cultures were detected in 1053 samples taken from 287 patients. Gram-negative bacilli constituted $55.1 \%$ of the 223 positive cultures. The most common microorganisms were Acinetobacter (16.6\%), Staphylococcus (14.8\%) and Klebsiella (10.8\%). Colistin resistance was found to be $8.3 \%$ in the Acinetobacter strains and resistance rates of $97-100 \%$ were observed to other antibiotic groups. Thirty-three staphylococcus were isolated, 17 were S. aureus and 16 were coagulase-negative Staphylococcus. While $29.4 \%$ of S. aureus were resistant to methicillin (MRSA), vancomycin resistance was not detected. Meanwhile, the MRSA ratio was $62.5 \%$, there was no vancomycin resistance among the coagulase-negative Staphylococcus. Klebsiella was the third most common microorganism and beta-lactamase producing Klebsiella strain was $62.5 \%$. Gentamycin was found to be the most susceptible antibiotic in Klebsiella strains with a resistance rate of 20.8\%. Pseudomonas aeruginosa constituted $9.4 \%$ of the cultures. While the resistance to colistin was not detected, resistance to piperacillin/tazobactam $42.8 \%$, tobramycin, imipenem and meropenem $50 \%$ and ceftazidime $61.9 \%$. The duration of hospitalization in patients with Acinetobacter isolated (23 [10-34] days vs 12.5 [5-24] days, $p=0.011)$ and the mortality rate $(62.5 \%$ vs $37.5 \%, p=0.008)$ were significantly higher than those who were not Acinetobacter isolated.

Conclusion: In conclusion, gram-negative bacilli constitute the majority of the patients in intensive care unit. Acinetobacter, the most common microorganism, has a high resistance rate and has been associated with prolonged hospitalization and mortality.

Key words: Antibiotic; infection; intensive care unit; resistance of antibiotic

\section{Gíiş̧}

Yoğun bakım ünitesinde takip ve tedavi edilen hasta grubunda hastaların genel durum bozuklarının olması ve bu hastalara invaziv işlemlerin sıklıkla uygulanmasından dolayı enfeksiyon gelişme riski, diğer servislerde yatan hastalara göre daha fazla, hastanede kalış süreleri daha uzundur $(1,2)$. Ayrıca bu hasta grubu, geniş spektrumlu antibiyotiklerin ampirik olarak yaygın ve kontrolsüz kullanımı nedeniyle dirençli enfeksiyonlara yatkın hastalardır. Dirençli etkenlerin neden olduğu enfeksiyonlar sadece mortalite ve morbiditeyi artırmakla kalmayıp, hastanede yatış süresinde uzama, maliyet ve komplikasyonlarda artışa sebep olmaktadır. Bu nedenle antibiyotiklere karşı giderek artan direnç, özellikle kritik hastaların ampirik tedavi seçiminde çok önemli bir sorundur $(3,4)$. Yoğun bakımda yüksek antibiyotik direnci nedeniyle, özellikle gram-negatif basil enfeksiyonlarında kullanılacak olan uygun ampirik antibiyotik tedavisini belirleyecek verilere gereksinim vardır. Yoğun bakım ünite- 
lerinde gelişen hastane enfeksiyonlarının etkenleri hastaneler, hatta hastane içindeki farklı yoğun bakım üniteleri arasında farklılık gösterdiği gibi, yoğun bakımın kendi ünitesi içerisinde de zamanla değişiklik gösterebilmektedir. Yoğun bakım ünitelerindeki enfeksiyonlarda hem tedavi seçimi hem de antibiyotik direnç oranını azaltmak için mikrobiyolojik hastalık etkenlerinin ve antibiyotik direnç profilinin belirlenmesi gerekmektedir $(1,4,5)$.

Bu çalışmada amaç, göğüs hastalıkları yoğun bakım ünitesinde farklı materyallerde üreyen mikroorganizmaları ve bunların antibiyotik direnç ve duyarlılık profillerini belirlemektir.

\section{MATERYAL ve METOD}

Çalışmamız, Ankara Üniversitesi Tıp Fakültesi Gögüs Hastalıkları Ana Bilim Dalı Yoğun Bakım Ünitesinde takip edilen hastalar ile prospektif olarak tasarlandı. Çalışma öncesinde Ankara Üniversitesi Tıp Fakültesi Etik Kurulundan 12.12.2016 tarihli 19-958-16 sayılı çalışma onayı alındı.

\section{Çalışma Hastaları}

Çalışmamıza Ankara Üniversitesi Tıp Fakültesi Göğüs Hastalıkları Anabilim Dalı yoğun bakım ünitesine Aralık 2016-Aralık 2017 tarihleri arasında 24 saatten uzun süre yatırılan hastalar dahil edildi. Yoğun bakımda 24 saatten daha kısa süreli takip edilen hastalar ve çalışmaya katılmayı kabul etmeyen hastalar kayıt dışı bırakıldı. Tüm hastalardan ya da hasta yakınlarından çalışma öncesi bilgilendirilmiş onam alındı.

\section{Hasta Verilerinin Toplanması}

Çalışmaya alınan tüm hastaların demografik verileri, ek hastalıkları, sigara kullanımı, evde uzun süreli oksijen tedavisi (USOT) kullanım durumu, evde invaziv (iMV) veya non-invaziv mekanik ventilatör (NIMV) tedavisi varlığı, varsa eşlik eden hastalıkları, Akut Fizyoloji ve Kronik Sağlık Değerlendirmesi (APACHE II) ve Ardışık Organ Yetmezliği Değerlendirme Skoru (SOFA) skorları kaydedildi.

Hastaların rutin bakılan tam kan, biyokimya, C-Reaktif protein (CRP), prokalsitonin (PCT) sonuçları kaydedildi. Hastalardan yoğun bakımda yatışları sürecinde gönderilen balgam, derin trakeal aspirat (DTA), kan, idrar, gaita ve varsa yara kültür örnekleri kaydedildi.

Balgam gram boyamada mikroskobun her alanında 10 'dan az epitel ve 25 'ten fazla polimormonükleer lökosit olan örneklerdeki kültür sonuçları değerlendirilmeye alındı. DTA kültürü için kantitatif kültür yapılanlarda $10^{5} \mathrm{cfu} / \mathrm{mL}$ ve üzeri, bronş lavajı için $10^{5}$ $\mathrm{cfu} / \mathrm{ml}$ ve üzeri, bronkoalveoler lavaj için $10^{4} \mathrm{cfu} / \mathrm{ml}$ üremeler anlamlı kabul edildi.

\section{İstatistiksel Analiz}

Çalışmamızda istatistiksel analizler için SPSS 20 paket programı kullanıldı. Sürekli değişkenlerde, normal dağılım gösteren veriler için ortalama ve_standart sapma, normal dağılım göstermeyen veriler için ortanca ve çeyrekler arası açıklık $\left[\mathrm{IQR}_{25-75}\right]$ değerleri verildi. Verilerin normal dağılımı Shapiro-Wilk testi ile değerlendirildi. Kategorik değişkenler sayı ve yüzde olarak bildirildi. Sürekli değişkenlerin parametrik test varsayımlarını karşılaması durumunda Student's $T$ test, karşılamıyorlarsa Mann-Whitney $U$ testi kullanıldı. Ölçümle elde edilen sürekli değişkenlerin iki grup arasında istatistiksel değerlendirilmesinde, iki ortalama arasındaki farkın önemlilik testi, sıralanabilir değişkenlerde ise Mann-Whitney-U testi kullanıldı. Kategorik değişkenler için gruplar arasında karşılaşııma amacıyla verilerin özelliğine göre ChiSquare veya Fisher' exact test kullanıldı. P değeri 0,05'in altında olan sonuçlar istatistiksel olarak anlamlı kabul edildi.

\section{BULGULAR}

Çalışma süresi boyunca 150'si erkek, 137'si kadın olmak üzere 287 hasta çalışmaya dahil edildi. Hastaların yaş ortalaması 69,96 $\pm 14,4$ yıl idi. íki yüz seksen yedi hastanın 272'sinde $(\% 94,8)$ en az bir komorbid hastalık mecuttu. Astım veya kronik obstrüktif akciğer hastalığı (KOAH) gibi obstrüktif akciğer hastalıkları, hipertansiyon ve kalp yetmezliği en sık görülen hastalıklar idi. Hastaların yoğun bakıma başlıca yatış endikasyonları solunum yetmezliği, pnömoni, KOAH akut alevlenme, kalp yetmezliği ve sepsisti. Çalışmaya alınmış hastaların demografik özellikleri, komorbid hastalıkları ve yoğun bakım ünitesine yatış nedenleri Tablo 1'de gösterilmiştir.

Çalışmamıza dahil edilen hastaların \% 45,6'sı USOT, \%17,8'i evde NiMV, \%1,7'si evde iMV tedavisi almaktaydı. Yoğun bakıma kabul sırasında \%46,6 hastaya yalnız medikal tedavi verilirken, \%42,8 hastaya ek olarak NiMV tedavisi, \%12,2 hastaya IMV tedavisi başlanmıştı. Hastaların takibi süresinde toplam \%46 hastaya NiMV, \%13,9 hastaya IMV tedavisi verilmişti. Hastaların yoğun bakım ünitesine kabulünün ilk 24 saatinde hesaplanan APACHE-II ve SOFA 
Tablo 1. Hastaların demografik özellikleri, komorbid hastalıkları

\begin{tabular}{|c|c|}
\hline Cinsiyet & n (\%) \\
\hline Kadın & $150(52,3)$ \\
\hline Erkek & $137(47,7)$ \\
\hline Yaş & $($ Ortalama $\pm S D)$ \\
\hline Kadın & $72,59 \pm 14,95$ \\
\hline Erkek & $67,56 \pm 13,48$ \\
\hline Sigara Öyküsü & n (\%) \\
\hline Hiç kullanmamış & $127(44,3)$ \\
\hline Kullanıp bırakmış & $148(51,6)$ \\
\hline Halen kullanıyor & $12(4,20)$ \\
\hline Komorbidite* & n $(\%)$ \\
\hline En az bir komorbidite varlığı & $272(94,8)$ \\
\hline $\mathrm{HT}$ & $174(60,6)$ \\
\hline $\mathrm{OAH}$ & $132(46)$ \\
\hline KKY & $93(32,4)$ \\
\hline ASKH & $77(26,8)$ \\
\hline DM & $75(26,1)$ \\
\hline Nörolojik patolojiler & $61(21,1)$ \\
\hline Atriyal fibrilasyon & $46(16)$ \\
\hline Solid organ maligniteleri & $32(11,1)$ \\
\hline Tiroid patolojileri & $28(9,8)$ \\
\hline KBY & $27(9,4)$ \\
\hline $\mathrm{KDH}$ & $22(7,7)$ \\
\hline OSAS & $22(7,7)$ \\
\hline PHT & $21(7,3)$ \\
\hline PTE & $14(4,9)$ \\
\hline Hematolojik maligniteler & $11(3,8)$ \\
\hline Kronik karaciğer hastalığı & $10(3,5)$ \\
\hline Yoğun bakım ünitesine yatış nedenleri* & n (\%) \\
\hline Solunum yetmezliği & $245(85,4)$ \\
\hline Pnömoni & $108(37,6)$ \\
\hline $\mathrm{KOAH}$ akut atak & $104(36,2)$ \\
\hline KKY & $78(27,2)$ \\
\hline iMV ihtiyacı & $72(25,1)$ \\
\hline Sepsis & $53(18,5)$ \\
\hline iAH akut atak & $45(15,7)$ \\
\hline Obezite hipoventilasyon & $38(13,2)$ \\
\hline PTE & $28(9,8)$ \\
\hline Plevral efüzyon & $26(9,1)$ \\
\hline Hemoptizi & $15(5,2)$ \\
\hline
\end{tabular}

HT: Hipertansiyon, OAH: Obstrüktif akciğer hastalığı, KKY: Konjestif kalp yetmezliği, ASKH: Aterosklerotik kalp hastalı̆̆ı, DM: Diyabetes mellitus, AF: Atriyal fibrilasyon, KBY: Kronik böbrek yetmezliği, OSAS: Obstrüktif uyku apne sendromu, KDH: Kollajen doku hastalı̆̆ı, PHT: Pulmoner hipertansiyon, PTE: Pulmoner tromboemboli, iMV: Invvaziv mekanik ventilasyon, IAH: İnterstisyel akciğer hastalığı.

*Bir hastada birden fazla komorbidite bulunabilmektedir. 
Tablo 2. Hastaların yoğun bakıma kabulü sırasındaki laboratuvar tetkik sonuçları

\begin{tabular}{|c|c|}
\hline Laboratuvar parametresi & $\mathrm{n}=287$ Ortanca $\left(\mathrm{IQR}_{25-75}\right)$ \\
\hline Kan Üre Azotu (BUN) (mg/dL) & $22(16-38)$ \\
\hline Kreatinin (mg/dL) & $0,91(0,63-1,27)$ \\
\hline Sodyum (mEq/L) & $140(136-143)$ \\
\hline Potasyum (mEq/L) & $4,3(3,8-4,7)$ \\
\hline Magnezyum (mg/dL) & $1,95(1,75-2,22)$ \\
\hline Fosfor $(\mathrm{mg} / \mathrm{dL})$ & $3,42(2,52-3,92)$ \\
\hline Total protein $(\mathrm{g} / \mathrm{dL})$ & $6,40(5,80-7,00)$ \\
\hline Albumin $(\mathrm{g} / \mathrm{dL})$ & $3,50(3,00-3,88)$ \\
\hline Total Bilirubin (mg/dL) & $0,66(0,43-0,58)$ \\
\hline Direk Bilirubin (mg/dL) & $0,23(0,15-0,37)$ \\
\hline İndirek Bilirubin (mg/dL) & $0,40(0,27-0,60)$ \\
\hline Alanin Amino Transferaz (U/L) & $19(14-30)$ \\
\hline Aspartat Amino Transferaz (U/L) & $24(16-33)$ \\
\hline Gama Glutamil Transferaz (U/L) & $27(16-58)$ \\
\hline Laktat Dehidrojenaz (U/L) & $243(193-331)$ \\
\hline Alkalen Fosfataz (U/L) & $76(62-107)$ \\
\hline Lökosit $\left(10^{9} / \mathrm{L}\right)$ & $8,93(7,42-12,31)$ \\
\hline Trombosit $\left(10^{9} / \mathrm{L}\right)$ & $235(172-328)$ \\
\hline Hemoglobin (g/dL) & $11,5(10,29-13,60)$ \\
\hline Hematokrit $(\%)$ & $36,8(32,2-42,8)$ \\
\hline C-Reactive Protein (CRP) (mg/L) & $56(15,9-133,8)$ \\
\hline Prokalsitonin $(\mathrm{ng} / \mathrm{mL})$ & $0,24(0,12-0,38)$ \\
\hline Sedimentasyon (mm/saat) & $31(15-56)$ \\
\hline
\end{tabular}

skorlama ortanca $\left[\mathrm{IQR}_{25-75}\right]$ değerleri sırasıyla 17 [12-23] ve 4 [2-6] idi. Hastaların yoğun bakım ünitesine kabulü sırasındaki laboratuvar tetkik sonuçları Tablo 2'de gösterilmiş̧tir.

Çalışma süresi boyunca yoğun bakım ünitesinde takip edilen 287 hastadan 1053 kültür örneği alındı ve bu kültürlerden 223'ünde üreme saptandı. Üreyen mikroorganizmalardan \%28,2'si trakeal aspiratta, $\% 25,5^{\prime} \mathrm{i}$ idrarda, \%15,2'si balgamda, \%14,7'si kanda, $\% 4,9^{\prime}$ u bronş lavajında, \%4,4'ü yara, \%2,6'sı kateter ucu örneklerinden izole edildi. En çok izole edilen mikroorganizma tüm üremelerin $\% 55,1$ 'ini oluşturan gram-negatif bakteriler olarak saptandı. Gram-negatif bakterilerden ise en sık izole edilen mikroorganizma Acinetobacter spp. $(\% 16,6)$ iken, bunu sırasıyla Klebsiella spp. (\%10,7) Pseudomonas spp. $(\% 9,4)$, E. coli $(\% 9,0)$ izlemekteydi. Üreyen mikroorganizmaların sıklığı ve izole edildikleri yere göre dağılımı Tablo 3'te gösterilmiştir.

Üreyen 37 Acinetobacter spp. suşunun \%75,6'sı solunum yolunda, \%13,5'i kanda saptanmıştı. Bu suşlarda kolistin direnci \%8,3 iken, çalışılan diğer antibiyotik gruplarına \%97-100 oranlarında direnç tespit edildi. Pseudomonas spp. suşlarında genişlemiş, spektrumlu beta-laktamaz direnci (ESBL) \%50 pozitif olarak saptandı. Klebsiella spp. suşlarında ise ESBL pozitifliği oranı \%62,5 idi. Gram-negatif basillerin antibiyotik direnç oranları Tablo 4'te gösterilmiştir.

Hastaların kültürlerinde üreyen gram-pozitif bakterilerde ise Staphylococcus aureus suşlarının $\% 29,4$ 'ünde metisilin direnci pozitif (MRSA) olarak bulunurken, hiçbirisinde vankomisin direnci saptanmadı. Koagülaz negatif stafilokok (KNS) suşlarında ise metisilin direnci \%62,5 iken, vankomisin direnci hiçbir suşta saptanmadı. Gram-pozitif bakterilerin antibiyotik direnç oranları Tablo 5'te gösterilmiştir.

Üreyen mikroorganizma ile hastaların yoğun bakımda yatış süresi arasındaki ilişkiye bakıldığında Acinetobacter spp. üremesi saptan hastalarda yoğun bakım yatış süresi, üreme olmayanlara göre anlamlı olarak daha uzun bulundu. $H$. influenzae üremesi saptanan hastalarda ise üreme olmayanlara göre yatış süresi daha kısa olarak saptandı. Üreyen mikroorganizma ve yatış süresi ilişkisi Tablo 6 'da gösterilmiştir.

Üreyen mikroorganizma ve mortalite arasındaki ilişkiye baktığımızda, Acinetobacter spp. suşları üreyen 


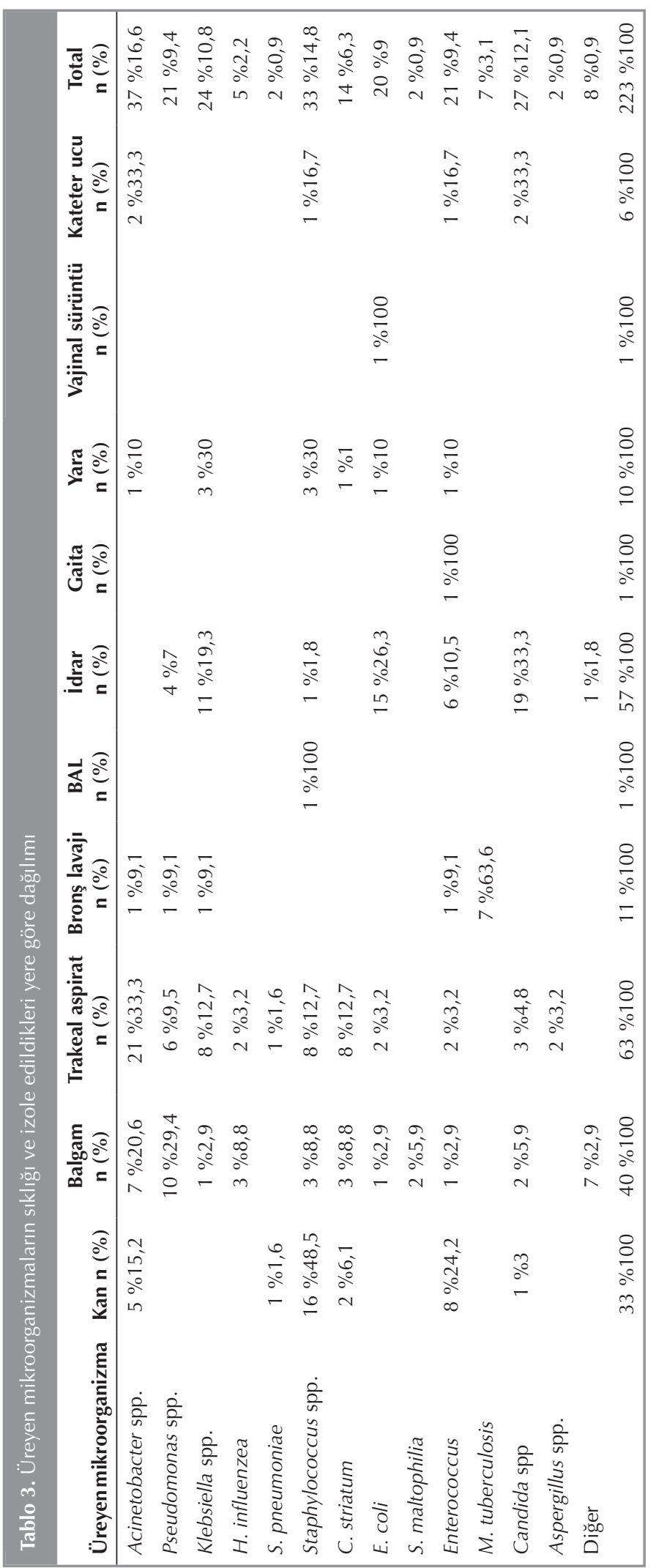

14 Tuberk Toraks 2021;69(1):9-20 
Tablo 4. Üreyen gram-negatif basillerin antibiyotik direnç oranları

\begin{tabular}{|c|c|c|c|c|}
\hline Direnç testi çalışılan antimikrobiyal ajan & $\begin{array}{c}\text { E. coli } \\
(\mathrm{n}=20)\end{array}$ & $\begin{array}{l}\text { Klebsiella spp } \\
\quad(n=24)\end{array}$ & $\begin{array}{l}\text { Pseudomonas spp. } \\
\quad(n=21)\end{array}$ & $\begin{array}{c}\text { Acinetobacter spp. } \\
\quad(n=37)\end{array}$ \\
\hline Ampisillin & $16 / 18(\% 88,8)$ & $23 / 24(\% 95,8)$ & & $2 / 2(\% 100)$ \\
\hline Sefuroksim & & $2 / 2(\% 100)$ & & \\
\hline Seftazidim & $1 / 2(\% 50)$ & $10 / 11(\% 90,9)$ & $13 / 21(\% 61,9)$ & $35 / 35(\% 100)$ \\
\hline Sefepim & $6 / 13(\% 46,1)$ & $14 / 15(\% 93,3)$ & $11 / 19(\% 57,8)$ & $15 / 15(\% 100)$ \\
\hline Piperasilin/Tazobaktam & $5 / 9(\% 55,8)$ & $17 / 18(\% 94,4)$ & $9 / 21(\% 42,8)$ & $34 / 35(\% 97,1)$ \\
\hline Sefoperazon/sulbaktam & & $3 / 4(\% 75)$ & $9 / 19(\% 47,3)$ & $30 / 32(\% 93,7)$ \\
\hline Amikasin & $0 / 8(\% 0)$ & $12 / 18(\% 66,6)$ & $15 / 21(\% 47,6)$ & $35 / 36(\% 97,2)$ \\
\hline Gentamisin & $7 / 18(\% 38,8)$ & $5 / 24(\% 20,8)$ & $17 / 21(\% 80,9)$ & $36 / 37(\% 97,3)$ \\
\hline TMP-SMX & $11 / 18(\% 61,1)$ & $10 / 24(\% 41,7)$ & & $35 / 35(\% 100)$ \\
\hline Spirofloksasin & $10 / 14(\% 71,4)$ & $13 / 14(\% 92,8)$ & $16 / 21(\% 76,2)$ & $24 / 24(\% 100)$ \\
\hline Levofloksasin & $2 / 3(\% 66,6)$ & $7 / 12(\% 58,3)$ & & 13/13 (\%100) \\
\hline İmipenem & $1 / 2(\% 50)$ & $11 / 14(\% 78,5)$ & $8 / 19(\% 42,1)$ & $21 / 21(\% 100)$ \\
\hline Meropenem & $1 / 1(\% 100)$ & $12 / 15(\% 80)$ & $11 / 21(\% 52,4)$ & $36 / 37(\% 97,3)$ \\
\hline Sefolotin & $13 / 19(\% 68,4)$ & $19 / 23(\% 82,6)$ & $0 / 1(\% 0)$ & \\
\hline Sefotaksim & $9 / 19(\% 47)$ & $16 / 23(\% 69,5)$ & $0 / 1(\% 0)$ & \\
\hline Seftriakson & & $4 / 4(\% 100)$ & & \\
\hline Tetrasklin & $1 / 1(\% 100)$ & $1 / 1(\% 100)$ & & 15/15 (\%100) \\
\hline Tigesiklin & & $14 / 14(\% 100)$ & & $32 / 32(\% 100)$ \\
\hline Tikarsillin/klavulonat & & & & 11/11 (\%100) \\
\hline Tobramisin & & & $2 / 4(\% 50)$ & \\
\hline Aztreonam & & $5 / 6(\% 83,3)$ & $1 / 1(\% 100)$ & $2 / 2(\% 100)$ \\
\hline Ertapenem & $1 / 9(\% 11,1)$ & $14 / 18(\% 77,7)$ & & \\
\hline Kolistin & & $6 / 13(\% 46,1)$ & $0 / 14(\% 0)$ & $3 / 36(\% 8,3)$ \\
\hline Nitrofurantion & $2 / 15(\% 13,3)$ & $9 / 11(\% 81,8)$ & & \\
\hline Netilmisin & & $5 / 5(\% 100)$ & $1 / 1(\% 100)$ & $21 / 21(\% 100)$ \\
\hline
\end{tabular}

hastalarda mortalite oranı üreme olmayanlara göre daha yüksek iken, Pseudomonas spp. üreyen hastalarda ise mortalite oranı üreme olmayanlara göre anlamlı olarak daha düşük saptandı. Üreyen mikroorganizmalar ve mortalite arasındaki ilişki Tablo 7'de gösterilmiştir.

Mekanik ventilasyon desteği verilen hastaların yoğun bakımda NIMV, IMV başarıları ile bu hastalarda üreyen mikroorganizmalar arasında anlamlı bir ilişki saptanmadı.

Çalışmaya dahil edilen hastaların yoğun bakıma yatışlarının ilk 24 saatinde hesaplanan APACHE-II ve SOFA skoru ile üreyen etkenlerin ilişkisine bakıldı- ğında, Acinetobacter üremesi saptanan hastaların APACHE-II ve SOFA skorları, üreme saptanmayanlara göre daha yüksekti. Pseudomonas üremesi saptanan hastaların APACHE-II ve SOFA skorları ise, üreme saptanmayanlara göre daha düşük olarak bulundu (Tablo 8).

\section{TARTIŞMA}

Çalışmamızdaki kültür üremelerinin \%55,1'lik kısmını gram-negatif bakteriler, \%25, 1'ini ise gram pozitif bakteriler oluşturmaktaydı. Gram-negatif bakterilerden suşlarından en sık izole edilen mikroorganizmalar sırasıyla Acinetobacter spp, Klebsiella spp, Pseudomonas spp., E. coli idi. Gram-pozitif bakteriler 
Yoğun bakım ünitesinde mikroorganizmaların dağılımı

\section{Tablo 5. Üreyen gram-pozitif basillerin antibiyotik direnç oranları}

\begin{tabular}{|c|c|c|c|c|}
\hline Direnç testi çalışılan antimikrobiyal ajan & S. aureus (17) & KNS (16) & S. pneumoniae (2) & Enterococcus (21) \\
\hline Ampisillin & & & & $12 / 18(\% 66,6)$ \\
\hline Amoksisilin/Klavulonat & $7 / 8(\% 87,5)$ & 9/9 (\%100) & & $1 / 1(\% 100)$ \\
\hline Penisillin & $13 / 13(\% 100)$ & $15 / 16(\% 93,7)$ & $0 / 1(\% 0)$ & \\
\hline Ertapenem & $1 / 1(\% 100)$ & $1 / 1(\% 100)$ & & $0 / 1(\% 0)$ \\
\hline Eritromisin & $9 / 12(\% 75)$ & $13 / 14(\% 92,8)$ & $0 / 1(\% 0)$ & \\
\hline Seftazidim & & & & $2 / 2(\% 100)$ \\
\hline Sefepim & & & & $1 / 1(\% 0)$ \\
\hline Sefalotin & $6 / 7(\% 85,7)$ & 9/9 (\%100) & & $1 / 1(\% 100)$ \\
\hline Sefazolin & $1 / 1(\% 100)$ & & & \\
\hline Piperasilin/Tazobaktam & & & & $0 / 1(\% 0)$ \\
\hline Quinopristin/Dalfopristin & & & & $6 / 14(\% 42,8)$ \\
\hline Rifampisin & $9 / 13(\% 69,2)$ & $8 / 16(\% 50)$ & & \\
\hline Gentamisin & $3 / 6(\% 50)$ & $5 / 7(\% 71,4)$ & & $7 / 16(\% 43,7)$ \\
\hline Klindamisin & $8 / 13(\% 61,5)$ & $13 / 15(\% 86,6)$ & $0 / 1(\% 0)$ & \\
\hline Linezolid & 0/12 (\%0) & 0/16 (\%0) & & 0/18 (\%0) \\
\hline TMP-SMX & $2 / 13(\% 15,3)$ & 8/16 (\%50) & 0/1 (\%0) & $2 / 2(\% 100)$ \\
\hline Spirofloksasin & $8 / 12(\% 66,6)$ & $15 / 16(\% 93,7)$ & & 6/6 (\%100) \\
\hline Levofloksasin & $1 / 1(\% 100)$ & & $1 / 1(\% 100)$ & $5 / 7(\% 71,4)$ \\
\hline İmipenem & & & & $0 / 1(\% 0)$ \\
\hline Mupirosin & $2 / 3(\% 66,6)$ & 4/5 (\%80) & & \\
\hline Moksifloksasin & $1 / 1(\% 100)$ & & & \\
\hline Sefotaksim & & & & $1 / 1(\% 100)$ \\
\hline Seftriakson & & 0/1 (\%0) & & \\
\hline Tetrasklin & $5 / 12(\% 41,6)$ & 8/16 (\%50) & & $3 / 3(\% 100)$ \\
\hline Tigesiklin & & & & 0/6 (\%0) \\
\hline Tikarsillin/klavulonat & & & $1 / 1(\% 100)$ & \\
\hline Teikoplanin & & & & $14 / 14(\% 100)$ \\
\hline Nitrofurantion & & & & $3 / 3(\% 100)$ \\
\hline Vankomisin & 0/12 (\%0) & 0/16 (\%0) & $0 / 1(\% 0)$ & $1 / 19(\% 5,2)$ \\
\hline
\end{tabular}

Tablo 6. Üreyen mikroorganizma ve hastaların yoğun bakım ünitesindeki yatış süresi ilişkisi

\begin{tabular}{|lccc|} 
& Yatış günü (gün) & Ortanca (IQR $\mathbf{2 5 - 7 5})$ & $\mathbf{p}$ \\
\cline { 2 - 4 } Üreyen mikroorganizma & Üreme var & Üreme yok & $\mathbf{0 , 0 1 1}$ \\
\hline Acinetobacter spp. & $23(10-34)$ & $12,5(5-24)$ & 0,202 \\
Pseudomonas spp. & $10(3-46)$ & $15(6-24)$ & 0,130 \\
Klebsiella spp. & $7(4,25-24)$ & $15(6-24)$ & $\mathbf{0 , 0 3 7}$ \\
H. influenzae & $4(2,5-10)$ & $15(6-24)$ & 0,534 \\
Staphylococcus spp. & $17(7,5-24)$ & $14(5-24)$ & 0,441 \\
E. coli & $13(2,75-22)$ & $15(6-24)$ & \\
\hline
\end{tabular}


Tablo 7. Üreyen mikroorganizmalar ve mortalite arasındaki ilişki

\begin{tabular}{|c|c|c|c|}
\hline Üreyen mikroorganizma & Eksitus (\%) & Yaşayan (\%) & $\mathbf{p}$ \\
\hline Acinetobacter spp. (+) & 62,5 & 37,5 & \multirow{2}{*}{0,008} \\
\hline Acinetobacter spp. (-) & 37,4 & 62,6 & \\
\hline Pseudomonas spp. (+) & 10 & 90 & \multirow{2}{*}{0,003} \\
\hline Pseudomonas spp. (-) & 44,6 & 55,4 & \\
\hline Klebsiella spp. (+) & 27,3 & 72,7 & \multirow{2}{*}{0,158} \\
\hline Klebsiella spp. (+) & 42,9 & 57,1 & \\
\hline H. influenzae (+) & 0 & 100 & \multirow{2}{*}{0,079} \\
\hline H. influenzae (-) & 42,3 & 57,7 & \\
\hline Staphylococcus spp. (+) & 36 & 64 & \multirow{2}{*}{0,569} \\
\hline Staphylococcus spp. (-) & 42 & 58 & \\
\hline E. coli $(+)$ & 42,9 & 57,1 & \multirow{2}{*}{0,900} \\
\hline E. coli $(+)$ & 41,1 & 58,9 & \\
\hline
\end{tabular}

Tablo 8. Üreyen mikroorganizma ve APACHE-II/SOFA skoru ilişkisi

\begin{tabular}{|lccc|} 
& APACHE II skoru ortanca $\left.\mathbf{( I Q R}_{\mathbf{2 5 - 7 5}}\right)$ & $\mathbf{p}$ \\
\hline & Var & Yok & $\mathbf{0 , 0 3 0}$ \\
Acinetobacter spp. & $26(16-35)$ & $21,5(13-27)$ & $\mathbf{0 , 0 3 6}$ \\
Pseudomonas spp. & $14,5(12-24,5)$ & $23(14-30)$ & 0,451 \\
Klebsiella spp. & $23(8-25)$ & $22(14-29)$ & 0,632 \\
H. influenzae & $15(11-30)$ & $22(13,75-28)$ & 0,811 \\
Staphylococcus spp. & $22(13,5-26)$ & $22(13,75-29,25)$ & 0,805 \\
E. coli & $20(12,75-31)$ & $50(14-28)$ & $\mathbf{p}$ \\
\hline & SOFA puanı (ortalama \pm SD) & 0,054 \\
\hline Acinetobacter spp. & $6(4-8)$ & Yok & 0,083 \\
Pseudomonas spp. & $4(3-5)$ & $6(3-6)$ & 0,456 \\
Klebsiella spp. & $4(4-6)$ & $5(4-7)$ & 0,986 \\
H. influenzae & $4(2,5-10,5)$ & $5(3-7)$ & 0,181 \\
Staphylococcus spp. & $5(4-8)$ & $4(3,75-7)$ & 0,559 \\
E. coli & $4,5(3-5,25)$ & $4(3,5-7)$ & \\
\hline
\end{tabular}

ise en sık Staphylococcus ve Enterococcus idi. Acinetobacter spp. suşlarında kolistin dışında tüm antibiyotiklere \%95 ve üzeri direnç saptandı. Ayrıca Acinetobacter spp. üremesi, uzamış hastanede yatış süresi, artmış APACHE-II ve SOFA skoru ile artmış mortalite ile ilişkili bulundu.

Yoğun bakım ünitesinde takip edilen hastalar dirençli enfeksiyonlara daha yatkın olup, hastanede kalış süreleri daha uzun hastalardır. Bunun yanı sıra, yıllar içerisinde enfeksiyon etkenleri ve direnç paternlerinde değişiklik olmaktadır. Yoğun bakım hastalarında önemli bir nozokomiyal enfeksiyon etkeni olan Acinetobacter spp. suşlarının görülme sıklığı son yıllarda artmış ve rutinde kullanılan geniş spektrumlu antibiyotiklere dirençli hale gelmiştir. Aynı zamanda tedavi sırasında yeni direnç mekanizmaları geliştirebilmektedir (6,7). Kliniğimiz yoğun bakımında 2012 yılında yapılmış olan başka bir çalışmada en sık izole edilen etkenler bizim çalışmamıza benzer olarak $\% 68,7$ oranı ile gram-negatif bakteriler olmakla birlikte, A. baumannii (\%13,7) oranı ile Pseudomonas ve MRSA'dan sonra üçüncü sıklıkta saptanmıştır (8). Bu 
durum aynı yoğun bakım ünitesinde bile zaman içerisinde mikroorganizmaların dağılımını değişebildiğini ve literatüre benzer şekilde Acinetobacter spp. suşlarında yıllar içerisinde artış olduğunu göstermektedir. Uluslararası, 75 ülke ve 1265 merkezin katıldığı yoğun bakımda enfeksiyon prevalansı ve sonuçları ile ilgili çalışmada tüm hastalarda Acinetobacter spp. yaklaşık \%8,8 sıklıkla ve gram-negatif mikroorganizmalar arasında üçüncü sırada saptanmıştır. Doğu Avrupa ve Asya'dan katılan merkezlerde ise bu sırasıyla \%17,1 ve \%19,2 sıklıkla görülmüştür (1).

Çalışmamızda üreyen Acinetobacter spp. suşlarının antibiyotik duyarlılıklarına baktığımızda kolistin direnci \%8,3 iken, diğer çalışılan antibiyotiklere direnç oranı \%95' in üzerinde saptanmıştır. Polonya'da yapılmış bir çalışmada Acinetobacter \%13,54 sıklıkta üremişti. Üreyen bu suşlarda kolistine direnç saptanmazken, meropenem ve imipeneme $\% 13$, levofloksasin ve siprofloksasine karşı ise \%15 oranında direnç saptamıştır (9). Literatürde çalışmalara bakıldığında Acinetobacter spp. insidansında ve direnç oranında hızlı bir artış olduğu görülmektedir ve ortaya çıkacak pan-rezistan suşların artışından endişe duyulmaktadır (7,10-12).

İmmün sistemi baskılanmış, bronşektazi, KOAH ve yapısal akciğer patolojileri olan hastalarda Pseudomonas spp. en önemli nozokomiyal patojenlerdendir $(13,14)$. Amerika Birleşik Devletleri genelinde ulusal hastane enfeksiyonları sürveyans sistemi ile ilgili yayınlanan verilerde yoğun bakım hastalarında solunum yolu enfeksiyonlarının \%18,1'ini, kan dolaşım enfeksiyonlarının \%3,4'ünü, cerrahi alan enfeksiyonlarının \%9, $5^{\prime}$ ini ve idrar yolu enfeksiyonlarının \%16,3'ünü Pseudomonas spp. oluşturduğu saptanmışır (7). Yoğun bakım ünitemizde daha önceden yapılmış olan çalışmada Pseudomonas suşları en sık saptanan mikroorganzima olup, meropenem direncinin $\% 70$, siprofloksasin ve piperasilin/tazobaktam dirençlerinin ise \%14 değerlerinde olduğu saptanmıştır. Aynı yoğun bakım ünitesinde on yıl ara ile yapılan bu iki çalışmada yıllar içerisinde pseudomonas suşlarının antibiyotik direncinde artış görülmektedir (8). Bununla birlikte Türkiye'deki Pseudomonas aeruginosa izolatlarının antibiyotik direnç oranlarının değerlendirildiği bir meta-analizde yıllar içerisinde Pseudomonas antibiyotik direncinin yıllar içinde azalma eğiliminde olduğu görülmüştür (15).
Klebsiella, majör fırsatçı enfeksiyonlardan birisi olup, nozokomiyal pnömoni, üriner sistem enfeksiyonları ve immünsüprese hastalarda bakteriyemi gibi çeşitli klinik tablolarda karşımıza çıkabilmektedir. Gelişen yüksek direnç oranlarıyla da özellikle gelişmiş ülkelerde önemli bir sorun haline gelmektedir. E. coli ile birlikte ESBL üreten en sık iki mikroorganizmadan birisidir (16). Vietnam'da üçüncü basamak bir hastanenin yoğun bakımında yatan hastaların dahil edildiği bir çalışmada ise Klebsiella suşlarının, Acinetobacter'den sonra en sık saptanan mikroorganizma olduğu saptanmıştır (17). Yapılan bir meta-analizde yoğun bakım hastalarından alınan izolatlarda üreyen Klebsiella suşlarının oranının giderek artış gösterdiği saptanmıştır. Bunun yanı sıra yüksek mortalite ile ilişkisi olduğu bildirilen karbapenem dirençli Klebsiella suşlarının da hızlı bir artış eğiliminde olduğu görülmüştür (18).

Normal koşullar altında gastrointestinal sistemde kommensal bir bakteri olan E. coli, uygunsuz konakçı koşulları varlığında, tıpkı diğer Enterobacteriaceae türleri gibi ölüme kadar gidebilen, enfeksiyonların kaynağı olabilirler. Özellikle yoğun bakımlarda ventilatör ilişkili pnömoniler ve kateter ilişkili üriner sistem enfeksiyonlarının önemli bir nedenini oluştururlar (19). Bizim çalışmamızda tüm üremelerin $\% 9^{\prime}$ unu $E$. coli oluşturmaktaydı ve suşların \%50 oranda ESBL üretmekteydi. Kliniğimiz yoğun bakımında daha önceden yapılmış olan çalışmada 115 kültür üremesinin \%26'sını E. coli suşları oluşturuyordu. Bu suşların da \%26,6'sı ESBL üretiyordu (8). Her iki çalışma arasında geçen 10 yıllık süre içerisinde yoğun bakımımızda E. coli üremelerinin azaldığı ancak, ESBL üreten $E$. coli oranının \% 26'dan \% 50'ye artış gösterdiği izlenmektedir.

Çalışmamızda Staphylococcus suşları, tüm üremelerin $\% 14,8^{\prime}$ inde görülmüş olup, bu suşların $\% 51,5^{\prime} \mathrm{i}$ Staphylococcus aureus, \%48,5'i ise KNS olarak saptanmıştır. Uluslararası çok merkezli yapılan bir çalışmada Staphylococcus aureus \%20,5 sıklıkla grampozitif mikroorganizmalar arasında ilk sırada saptanmıştır. Doğu Avrupa ve Asya'dan katılan merkezlerde ise bu sırasıyla $\% 19,6$ ve $\% 16,1$ sıklıkla görülmüştür, kültürlerin \%10,2'sinde ise metisillin dirençi pozitif saptanmıştır. Doğu Avrupa ve Asya'dan katılan merkezlerde ise metisillin direnci sırasıyla $\% 10,4$ ve $\% 10$ sıklıkla görülmüştür (1) Literatürde görüldüğü üzere metisilin direnci \%10-80 arasında geniş bir aralıkta değişmektedir $(20,21)$. 
Üreyen mikroorganizmalar ile hastaların yoğun bakımda yatış süreleri arasındaki ilişki incelendiğinde, Acinetobacter spp. üremesi saptan hastalarda yoğun bakım yatış süresi, üreme olmayanlara göre daha uzun bulunmuştur. $H$. influenzae üremesi saptanan hastalarda ise yatış süresi daha kısa olarak saptanmıştır. Sileem ve arkadaşları tarafından yapılan Acinetobacter spp. nedenli ortaya çıkan yoğun bakım enfeksiyonlarının değerlendirildiği çalışmada, Acinetobacter spp. üremesi saptanan hastaların yoğun bakımda yatış süresi, üreme olmayanlara göre anlamlı olarak yüksek saptanmıştır (22). İki bin on beş yılında yayınlanmış başka bir yoğun bakım çalışmasında da Acinetobacter baumannii üremesi saptanan hastaların yoğun bakım yatış süresi, çalışmamıza benzer şekilde daha yüksek saptanmıştır (5). Kanada'da yapılmış başka bir çalışmada $P$. aeruginosa üremelerinin oranının uzamış hastane yatışlarında artmış olduğu bulunmuştur. Ayrıca aynı çalışmada $H$. influenzae üremelerinin hastane yatışlarının erken dönemlerinde daha yüksek oranlarda saptandığı bulunmuştur (23). Bu durumun, $H$. influenzae toplum kökenli pnömoni etkenlerinden birisi olması nedeniyle yoğun bakıma ya da hastaneye yatışların erken döneminde saptanması ve antibiyotik direnç oranlarının görece daha düşük olması ve dolayısıyla tedavi sürelerinin daha kısa olması durumu ile ilişkili olabileceğini düşünmekteyiz.

Çalışmamızda alınan kültürlerde üreyen etkenler ile mortalitearasındaki ilişki incelendiğinde Acinetobacter suşlarının ürediği hastalarda mortalite üreme olmayanlara göre daha yüksek, Pseudomonas spp. üreyen hastalarda ise mortalite oranı, üreme olmayanlara göre daha düşük saptanmıştır. Nazer ve arkadaşlarının yoğun bakım ünitelerinde yapmış oldukları bir çalışmada da Acinetobacter üremelerinin mortalite için bağımsız bir risk faktörü olduğu saptanmıştır (5). Sileem ve arkadaşlarının çalışmasında da Acinetobacter üremesi olan grupta mortalite, üreme olmayan gruba göre daha yüksek bulunmuştur (22).

Çalışmamızda, hastaların yoğun bakıma yatışlarının ilk 24 saatinde hesaplanan APACHE-II skorlarına baktığımızda Acinetobacter üremesi olan grup, üreme olmayanlara göre daha yüksek skora sahipken; Pseudomonas üremesi olanlar, üreme olmayanlara göre daha düşük APACHE-II skoruna sahipti. Acinetobacter spp. nozokomiyal etkenlerden olup, yüksek antibiyotik direnç oranları mevcuttur. Özellikle ventilatöre bağlı hastalarda solunum yolu enfeksiyonları, idrar yolu enfeksiyonları ve bakteriye- miler ile ilişkili olması nedeniyle uzun süreli hastane yatışları, artmış komplikasyonlar ve mortalite görülebilir. $P$. aeruginosa'da nozokomiyal bir enfeksiyon etkeni olmakla birlikte, solunum yollarında, cilt ve gastrointestinal sistemde kolonize olarak bulunabilmektedir (24). Çalışmamızdaki hastaların da büyük bir kısmında KOAH, bronşektazi gibi Pseudomonas kolonizasyonun sık olduğu klinik durumlar mevcuttu. Aktif enfeksiyonu olmadığı halde, kolonizasyon nedeni ile Pseudomonas suşları üreyen hastalar nedeni ile Pseudomonas üreyen grupta mortalitenin ve APACHE-II skorunun daha düşük olabileceğini düşünmekteyiz.

Çalışmamızın bazı kısıtlııkları mevcuttu. Birincisi; çalışmada özellikle solunum yolu örneklerinde üreyen mikroorganizmaların aktif enfeksiyon etkeni mi yoksa kolonizasyona mı bağlı olduğunun net değerlendirilememiş olması bir çalışma kısıtlılığı olarak kabul edilmiştir. Diğer bir kısıtlılık ise; çalışma bulgularımızın, hastaların yaşı ve ek hastalıklarından bağımsız olarak değerlendirilmemiş olmasıdır.

Sonuç olarak, yoğun bakım ünitelerinde hastane enfeksiyonları ve antibiyotik direnci önemli bir sorundur. Antibiyotiklere karşı giderek artan direnç nedeniyle, özellikle kritik hastaların ampirik tedavisinde güncel etken dağııımı ve direnç profillerinin değerlendirildiği veriler dikkate alınarak tedavi planlamaları yapılmalıdır.

Etik Komite Onayı: Çalışma için Ankara Üniversitesi Tıp Fakültesi Etik Kurulundan onay alındı (Karar no: 19-958-16, Tarih 12.12.2016).

\section{ÇIKAR ÇATIŞMASI}

Yazarlar çıkar çatışması bildirmemiştir.

\section{YAZAR KATKISI}

Anafikir/Planlama: HH, AKG, AÇ, AK

Analiz/Yorum: HH, AGK, AÇ, SE, FÇ, HG, AK

Veri sağlama: $\mathrm{HH}, \mathrm{AKG}, \mathrm{AÇ,} \mathrm{SE,} \mathrm{FÇ,} \mathrm{HG,} \mathrm{AK}$

Yazım: HH, AKG, AÇ

Gözden Geçirme ve Düzeltme: HH, AKG, AÇ, SE, FÇ, HG, AK

Onaylama: HH, AKG, AÇ, SE, FÇ, HG, AK

\section{KAYNAKLAR}

1. Vincent JL, Rello J, Marshall J, Silva E, Anzueto A, Martin $C D$, et al. International study of the prevalence and outcomes of infection in intensive care units. JAMA 2009, 302(21): 2323-9. 
2. Torres A, Niederman MS, Chastre I, Ewig S, FernandezVandellos P, Hanberger $\mathrm{H}$, et al. International ERS/ESICM/ ESCMID/ALAT guidelines for the management of hospitalacquired pneumonia and ventilator-associated pneumonia: Guidelines for the management of hospital-acquired pneumonia (HAP)/ventilator-associated pneumonia (VAP) of the European Respiratory Society (ERS), European Society of Intensive Care Medicine (ESICM), European Society of Clinical Microbiology and Infectious Diseases (ESCMID) and Asociacion Latinoamericana del Torax (ALAT). Eur Respir J 2017; 50(3).

3. Ciftci F, Mulazimoglu DD, Erol S, Ciledag A, Kaya A. Effect of sputum bacteriology on the prognosis of patients with acute exacerbations of bronchiectasis in the intensive care unit. Eurasian J Pulmonol 2018; 20(2): 85-92.

4. Campion M, Scully G. Antibiotic use in the Intensive care unit: optimization and de-escalation. I Intensive Care Med 2018; 33(12): 647-55.

5. Nazer LH, Kharabsheh A, Rimawi D, Mubarak S, Hawari F. Characteristics and outcomes of acinetobacter baumannii Infections in critically Ill patients with cancer: a matched case-control study. Microb Drug Resist 2015; 21(5): 556-61.

6. Jamal S, Al Atrouni A, Rafei R, Dabboussi F, Hamze $M$, Osman M. Molecular mechanisms of antimicrobial resistance in Acinetobacter baumannii, with a special focus on its epidemiology in Lebanon. J Glob Antimicrob Resist 2018; 15: 154-63.

7. Falagas ME, Kopterides P. Risk factors for the isolation of multi-drug-resistant Acinetobacter baumannii and Pseudomonas aeruginosa: a systematic review of the literature. J Hosp Infect 2006; 64(1): 7-15.

8. Yalçın A, Şen E, Erol S, Çiledağ A, Gülbay B, Önen Z. Solunum yoğun bakım ünitemizdeki enfeksiyon etkenleri ve direnç sorunu. Ortadoğu Med J 2013; 5(5): 17-24.

9. Ziolkowski G, Pawlowska I, Krawczyk L, Wojkowska-Mach J. Antibiotic consumption versus the prevalence of multidrug-resistant Acinetobacter baumannii and Clostridium difficile infections at an ICU from 2014-2015. I Infect Public Health 2018; 11(5): 626-30.

10. Sohail M, Rashid A, Aslam B, Waseem M, Shahid M, Akram $M$, et al. Antimicrobial susceptibility of Acinetobacter clinical isolates and emerging antibiogram trends for nosocomial infection management. Rev Soc Bras Med Trop 2016; 49(3): 300-4.

11. Bacakoglu F, Korkmaz Ekren P, Tasbakan MS, Basarik B, Pullukcu H, Aydemir S, et al. Multidrug-resistant Acinetobacter baumannii infection in respiratory intensive care unit. Mikrobiyol Bul 2009; 43(4): 575-85.

12. Aliskani H, Colakoglu S, Turunc T, Demiroglu YZ, Erdogan $F$, Akin $S$, et al. Four years monitorization of antibiotic sensitivity rates of Pseudomonas aeruginosa and Acinetobacter baumannii strains isolated from patients in intensive care unit and inpatient clinics. Mikrobiyol Bul 2008; 42(2): 321-9.
13. Ciftci F, Sen E, Saryal SB, Onen ZP, Gulbay B, Yildiz O, et al. The factors affecting survival in patients with bronchiectasis. Turk J Med Sci 2016; 46(6): 1838-45.

14. Restrepo MI, Babu BL, Reyes LF, Chalmers JD, Soni NJ, Sibila $O$, et al. Burden and risk factors for Pseudomonas aeruginosa community-acquired pneumonia: a multinational point prevalence study of hospitalised patients. Eur Respir J 2018; 52(2).

15. Aykan SB, Ciftci IH. Changes in antibiotic resistance of Pseudomonas aeruginosa isolates over the past 11 years in Turkey: a meta-analysis. Mikrobiyol Bul. 2015; 49(3): 35265.

16. Sekowska A, Gospodarek E, Kusza K. The prevalence of infections and colonisation with Klebsiella pneumoniae strains isolated in ICU patients. Anaesthesiol Intensive Ther 2014; 46(4): 280-3.

17. Tran GM, Ho-Le TP, Ha DT, Tran-Nguyen CH, Nguyen TSM, Pham TTN, et al. Patterns of antimicrobial resistance in intensive care unit patients: a study in Vietnam. Bmc Infect Dis 2017; 17(1): 429.

18. Xu L, Sun X, Ma X. Systematic review and meta-analysis of mortality of patients infected with carbapenem-resistant Klebsiella pneumoniae. Ann Clin Microbiol Antimicrob 2017; 16(1): 18.

19. Wujtewicz MA, Sledzinska A, Owczuk R, Wujtewicz M. Escherichia coli bacteraemias in intensive care unit patients. Anaesthesiol Intensive Ther 2016; 48(3): 171-4.

20. Thuy DB, Campbell I, Nhat LTH, Hoang NVM, Hao NV, Baker S, et al. Hospital-acquired colonization and infections in a Vietnamese intensive care unit. PLoS One 2018; 13(9): e0203600.

21. Momtaz H, Hafezi L. Meticillin-resistant Staphylococcus aureus isolated from Iranian hospitals: virulence factors and antibiotic resistance properties. Bosn J Basic Med Sci 2014; 14(4): 219-26.

22. Sileem A, Said A, Meleha M. Acinetobacter baumannii in ICU patients: A prospective study highlighting their incidence, antibiotic sensitivity pattern and impact on ICU stay and mortality. Egypt / Chest Dis Tu 2017; 66(4): 6938.

23. Wanis $M$, Walker SAN, Daneman N, Elligsen $M$, Palmay $L$, Simor A, et al. Impact of hospital length of stay on the distribution of Gram negative bacteria and likelihood of isolating a resistant organism in a Canadian burn center. Burns 2016; 42(1): 104-11.

24. Valderrey AD, Pozuelo MJ, Jimenez PA, Macia MD, Oliver $A$, Rotger R. Chronic colonization by Pseudomonas aeruginosa of patients with obstructive lung diseases: cystic fibrosis, bronchiectasis, and chronic obstructive pulmonary disease. Diagn Microbiol Infect Dis 2010; 68(1): 20-7. 